\title{
Indonesian Cultural Interference Against the Use of Sumimasen
}

\author{
Febi Ariani Saragih \\ Universitas Brawijaya \\ Malang, Indonesia \\ febiwahyusantoso@gmail.com
}

\author{
Masilva Raynox Mael \\ Universitas Negeri Surabaya \\ Surabaya, Indonesia \\ masilvamael@unesa.ac.id
}

\author{
Henry Agung Setiawan Thamin \\ Universitas Brawijaya \\ Malang, Indonesia \\ henryagungs@gmail.com
}

\begin{abstract}
In the process of learning a foreign language, it is necessary to understand the culture of it. It is useful to know the views or mindset where the foreign language is originated. The lack of knowledge about the culture which the foreign language originated will lead to interference of the learners' natural cultures toward the use of the foreign language they learn. For example, the word sumimasen in Japanese which is used by Japanese culture has many meanings and it is used in various contexts of conversation. Therefore, the aim of this research is to examine the interference of Indonesian culture toward the use of the word sumimasen. The method of this research is qualitative approach. The data were obtained by distributing questionnaires to students of Literature Study Program. The data analysis was done by collecting and tabulating answers from questionnaires, then formulated and described using sentences briefly. The results showed that interference is found in the use of the word sumimasen which functions as a gratitude marker or a "thank you" sign. It is because of the difference concepts of 'thank you' meaning in Indonesian culture which contains no remorse.
\end{abstract}

\section{Keywords-interference; culture; sumimasen}

\section{INTRODUCTION}

In the Japanese language learning, there are some frequently used words in the daily conversations like arigatogozaimasu (thank you so much), sumimasen (excuse me, so sorry, and thank you), gomennasai (sorry), and shitsureishimasu (excuse me/sorry). Those Japanese words in Indonesian language have various meanings (contains more than one meaning). This can be one of the difficulties for Japanese language learners.

The word sumimasen can represent "excuse me", "sorry", and "thank you" at the same situation. It is because the word sumimasen can have more than one meaning, it is often found an error practice of using sumimasen beyond its meaning of "sorry". There is no exception for the students of Japanese literature study program of cultural science faculty in Brawijaya University of Malang.

The use of sumimasen in the context of Japanese conversation is influenced by the Japanese culture of hon'ne and other cultures. The culture that influences the use of word sumimasen is often found in Indonesian culture. This issue causes Indonesian culture interference toward the use of Japanese language, the use of sumimasen in particular.

Based on this issue, it is done such research about Indonesian cultural interference against the use of word Sumimasen of the students at Japanese literature study program academic year 2014

\section{A. Interference}

Interference is a mistake that happens due to the inclusion of speech habits from mother tongue or dialect into the other languages or second dialect.

Language or second dialect has different structure of that mother tongue so that the use of them is not the same with the mother tongue. The use of the structure in mother tongue or dialect to both languages causes interference to happen [1].

Interference occurs because the ability of B2 speakers is much lower to the ability of B1 so that it is called multiple language abilities. The ability of multiple languages usually has difficulty in using B2 because of the influence of B1 [3]

\section{B. The Function of Sumimasen}

Kimura [6] identifies five functions of Sumimasen in his research entitled The Multiple Functions of Sumimasen. The word functions for Sumimasen are: 1) Request Marker, 2) Attention-Attractor, 3) Closing Marker, 4) Regret Marker, and 5) Gratitude Marker.

\section{Sumimasen in Cultural Context}

Enomoto [4] in his book Sumimasen that Japanese people cannot clearly state what they want to express, use many ambiguous expressions, do not make sense, so that they want the speaker or interlocutor to always think or guess for themselves what is meant by the conversation. From these conditions in Japanese culture there are those called hon'ne = true intent and tatemae $=$ pleasantries. The use of sumimasen is representative of that culture. Enomoto [4] gave a more detailed explanation about the cultural factors of using sumimasen, namely: prioritizing harmony; there is an acknowledgment that admitting mistakes by apologizing is beautiful "elegance"; urging people to apologize elegantly, not to do things like 
pursuing responsibility; insisted that "I was the right one" was selfish and not worth seeing; always thinking in the position of the other person, and having a high level of empathy; attaches importance to shared reputation.

\section{METHOD}

This research is a qualitative research employing an observation of a phenomenon or social phenomenon [5]. They are used as the source of data. This approach is based on the reality (empirical). The data is collected by using the questionnaire. It is in the form of a Japanese conversation questions about the use of sumimasen that has been distributed to the respondents and returned to the researcher to be analyzed.

\section{RESULTS AND DISCUSSION}

Questionnaire questions were taken from Kiku Kangeru Hanasu Ryuugakusei no Tame no Shokyuu Nihongo Kaiwa [7] and Isshoni Ite Tanoshii Hito.Tsukareru Hito [2]. The questionnaire for the students at Japanese literature study program in the academic year 2014 has been distributed to analyze the Indonesian cultural interference toward the use of sumimasen. The followings are the findings and the discussion that have been gained by the researcher from the respondents' answer based on the function of the word Sumimasen.

\section{A. The word Sumimasen as Regret Marker}

Here are the findings from the respondents' answer:

TABLE I. SUMIMASEN (REGRET MARKER)

\begin{tabular}{|c|c|c|c|}
\hline Fungsi Kata & $\begin{array}{l}\text { Arigatougozaimasu } \\
\text { (A) }\end{array}$ & $\begin{array}{l}\text { Shitsureishimasu } \\
\text { (B) }\end{array}$ & $\begin{array}{l}\text { Sumimasen } \\
\text { (C) }\end{array}$ \\
\hline Request Marker (A) & 0 & 0 & 1 \\
\hline Attention-getter (B) & 0 & 0 & 0 \\
\hline Closing Marker (C) & 2 & 0 & 1 \\
\hline Regret Marker (D) & 0 & 1 & 17 \\
\hline Gratitude Marker (E) & 8 & 0 & 0 \\
\hline
\end{tabular}

TABLE II. SUMIMASEN (REGRET MARKER)

\begin{tabular}{|l|c|c|c|}
\hline \multicolumn{1}{|c|}{ Pilihan Kata } & $\begin{array}{c}\text { Arigatougozaimasu } \\
\text { (A) }\end{array}$ & $\begin{array}{c}\text { Shitsureishimasu } \\
\text { (B) }\end{array}$ & $\begin{array}{c}\text { Sumimasen } \\
\text { (C) }\end{array}$ \\
\hline Request Marker (A) & 0 & 0 & 1 \\
\hline Attention-getter r (B) & 0 & 0 & 1 \\
\hline Closing Marker (C) & 0 & 0 & 0 \\
\hline Regret Marker r (D) & 0 & 0 & 24 \\
\hline Gratitude Marker (E) & 3 & 0 & 1 \\
\hline
\end{tabular}

Based on the findings and the discussion of the Sumimasen word that function as a regret marker, it can be concluded that there is no Indonesian cultural interference toward the use of the word Sumimasen. The absence of Indonesian cultural interference toward the use of sumimasen as regret marker is caused by the use of word "sorry" and sumimasen as the regret marker in the Indonesian culture and Japanese culture. They are almost the same. As a result, it is not found the misusage of that word.

\section{B. The word Sumimasen as Gratitude Marker}

Here are the findings from the respondents' answer:

TABLE III. SUMIMASEN (GRATITUDE MARKER)

\begin{tabular}{|l|c|c|c|}
\hline \multicolumn{1}{|r|}{ Pilihan Kata } & $\begin{array}{c}\text { Arigatougozaimasu } \\
\text { (A) }\end{array}$ & $\begin{array}{c}\text { Shitsureishimasu } \\
\text { (B) }\end{array}$ & $\begin{array}{c}\text { Sumimasen } \\
\text { (C) }\end{array}$ \\
\hline Fungsi Kata & 0 & 4 & 4 \\
\hline Request Marker (A) & 0 & 3 & 3 \\
\hline Attention-getter (B) & 0 & 1 & 0 \\
\hline Closing Marker (C) & 0 & 1 & 3 \\
\hline Regret Marker (D) & 0 & 0 & 2 \\
\hline Gratitude Marker (E) & 8 & & \\
\hline
\end{tabular}

TABLE IV. SUMIMASEN (GRATITUDE MARKER)

\begin{tabular}{|c|c|c|c|}
\hline Fungsi Kata & $\begin{array}{c}\text { Arigatougozaimasu } \\
\text { (A) }\end{array}$ & $\begin{array}{l}\text { Shitsureishimasu } \\
\text { (B) }\end{array}$ & $\begin{array}{l}\text { Sumimasen } \\
\text { (C) }\end{array}$ \\
\hline Request Marker (A) & 1 & 0 & 2 \\
\hline Attention-getter (B) & 0 & 1 & 0 \\
\hline Closing Marker (C) & 1 & 2 & 1 \\
\hline Regret Marker (D) & 0 & 0 & 0 \\
\hline Gratitude Marker (E) & 18 & 0 & 4 \\
\hline
\end{tabular}

There is Indonesian culture interference toward the use of sumimasen as gratitude marker. This interference happens because there is a cultural difference between Japanese and Indonesian in uttering gratitude. The researcher thinks that the respondents were less familiar with the use of the word sumimasen as gratitude marker or something to be used to say thanks.

This thin $\mathrm{g}$ is caused by the respondents that they are unable to understand the cultural background of the word sumimasen as gratitude marker. Another case to be considered that the respondents generally used arigatougozaimasu as gratitude marker, so that the respondents would prefer choosing arigatougozaimasu without considering about any conversational context and Japanese cultures that reflects the conversation.

The word sumimasen in the context of Indonesian conversation reflects that there is no guilty or regret feeling because of getting any help or good deeds from other people. The word sumimasen in the context of Indonesian conversation reflects that the recipient of help does not see himself as a trouble maker. It can also be someone who has got something from the person who has given his help or kindness.

The word sumimasen as gratitude marker in the context of Japanese conversational context on the other hand has a different point of view that it does reflects gratitude. It also reflects guilty or regrets because he has got help or good deed form other people. Therefore, it concludes that the Indonesian language interference toward the use of sumimasen as gratitude marker is caused by the different concepts of thanking in the context of Indonesian daily conversation.

\section{The word Sumimasen as Request Marker}

Here are the findings from the respondents' answer: 
TABLE V. SUMIMASEN (REQUEST MARKER)

\begin{tabular}{|c|c|c|c|}
\hline Fungsi Kata & $\begin{array}{l}\text { Arigatougozaimasu } \\
\text { (A) }\end{array}$ & $\begin{array}{l}\text { Shitsureishimasu } \\
\text { (B) }\end{array}$ & $\begin{array}{l}\text { Sumimasen } \\
\text { (C) }\end{array}$ \\
\hline Request Marker (A) & 0 & 0 & 14 \\
\hline Attention-getter (B) & 0 & 2 & 13 \\
\hline Closing Marker (C) & 0 & 0 & 0 \\
\hline $\begin{array}{ll}\text { Regret Marker } & \text { (D) }\end{array}$ & 0 & 0 & 1 \\
\hline Gratitude Marker (E) & 0 & 0 & 0 \\
\hline
\end{tabular}

TABLE VI. SUMIMASEN (REQUEST MARKER)

\begin{tabular}{|l|c|c|c|}
\hline Pungsi Kata & $\begin{array}{c}\text { Arigatougozaimasu } \\
\text { (A) }\end{array}$ & $\begin{array}{c}\text { Shitsureishimasu } \\
\text { (B) }\end{array}$ & $\begin{array}{c}\text { Sumimasen } \\
\text { (C) }\end{array}$ \\
\hline Request Marker (A) & 0 & 0 & 16 \\
\hline Attention-getter r (B) & 0 & 4 & 7 \\
\hline Closing Marker (C) & 1 & 0 & 0 \\
\hline Regret Marker (D) & 0 & 0 & 0 \\
\hline Gratitude Marker (E) & 2 & 0 & 0 \\
\hline
\end{tabular}

Based on the finding, the use of sumimasen as request marker above, it concludes that there is no Indonesian cultural interference phenomenon. It may be caused that asking for help' tradition between Indonesian and Japan is identical. Moreover, the respondents have understood and been accustomed to it.

The absence of Indonesian cultural interference toward the use of sumimasen as request marker happens because the Indonesian citizens normally use sumimasen that has been translated into Indonesian as "sorry". It is used because there is an assumption that the speaker interrupts and distract listener who is doing something. The assumption when using the word "sorry" as request marker is as the same as using the word sumimasen as request marker in the context of Japanese conversation.

For that reason, it concludes that the absence of Indonesian cultural interference for the word sumimasen as request marker is caused by the cultural and mindset similarity that emphasize the harmony and deep thinking to the listener in term of Indonesian or Japanese conversational context.

\section{The word Sumimasen as Attention-getter}

Here are the findings from the respondents' answer:

TABLE VII. SUMIMASEN ATTENTION-GETTER

\begin{tabular}{|l|c|c|c|}
\hline Pungsi Kata & $\begin{array}{c}\text { Arigatougozaimasu Kata } \\
\text { (A) }\end{array}$ & $\begin{array}{c}\text { Shitsureishimasu } \\
\text { (B) }\end{array}$ & $\begin{array}{c}\text { Sumimasen } \\
\text { (C) }\end{array}$ \\
\hline Request Marker (A) & 0 & 0 & 9 \\
\hline Attention-getter (B) & 0 & 2 & 19 \\
\hline Closing Marker (C) & 0 & 0 & 0 \\
\hline Regret Marker (D) & 0 & 0 & 0 \\
\hline Gratitude.Marker (E) & 0 & 0 & 0 \\
\hline
\end{tabular}

TABLE VIII. SUMIMASEN ATTENTION-GETTER

\begin{tabular}{|c|c|c|c|}
\hline Fungsi Kata & $\begin{array}{c}\text { Arigatougozaimasu } \\
\text { (A) }\end{array}$ & $\begin{array}{l}\text { Shitsureishimasu } \\
\text { (B) }\end{array}$ & $\begin{array}{l}\text { Sumimasen } \\
\text { (C) }\end{array}$ \\
\hline Request Marker (A) & 0 & 0 & 4 \\
\hline Attention-getter (B) & 0 & 2 & 23 \\
\hline Closing Marker (C) & 0 & 0 & 0 \\
\hline $\begin{array}{ll}\text { Regret Marker } & \text { (D) }\end{array}$ & 0 & 0 & 1 \\
\hline Gratitude Marker (E) & 0 & 0 & 0 \\
\hline
\end{tabular}

Based on the result of the use of sumimasen as attentiongetter, it is found that there is no Indonesian culture interference toward the use of the word sumimasen as attention-getter.

This phenomenon is caused by the "culture of calling people" or attention-getter between Indonesian and Japan which has the similarity with Indonesian languages.

The absence of Indonesian culture interference phenomenon toward the use of sumimasen as attention-getter is caused by the use of sumimasen word which is either used to attract the listener or simply to start the conversation. That similar function leads the Indonesian cultural interference to be ignored in the use of sumimasen as attention-getter. It concludes that the devoid of Indonesian cultural interference toward the use of sumimasen as attention-getter is also caused by the same summimasen word function in either Indonesian or Japanese conversational context.

E. The word Sumimasen as Closing Marker

Here are the findings from the respondents' answer:

TABLE IX. SUMIMASEN CLOSING MARKER

\begin{tabular}{|c|c|c|c|}
\hline Fungsi Kata & $\begin{array}{l}\text { Arigatougozaimasu } \\
\text { (A) }\end{array}$ & $\begin{array}{l}\text { Shitsureishimasu } \\
\text { (B) }\end{array}$ & $\begin{array}{l}\text { Sumimasen } \\
\text { (C) }\end{array}$ \\
\hline Request Marker (A) & 0 & 0 & 0 \\
\hline Attention-getter (B) & 0 & 0 & 1 \\
\hline Closing Marker (C) & 5 & 16 & 2 \\
\hline $\begin{array}{ll}\text { Regret Marker } & \text { (D) }\end{array}$ & 0 & 0 & 0 \\
\hline Gratitude Marker (E) & 6 & 0 & 0 \\
\hline
\end{tabular}

TABLE X. SUMIMASEN CLOSING MARKER

\begin{tabular}{|c|c|c|c|}
\hline Fungsi Kata & $\begin{array}{c}\text { Arigatougozaimasu } \\
\text { (A) }\end{array}$ & $\begin{array}{l}\text { Shitsureishimasu } \\
\text { (B) }\end{array}$ & $\begin{array}{l}\text { Sumimasen } \\
\text { (C) }\end{array}$ \\
\hline Request Marker (A) & 0 & 0 & 0 \\
\hline Attention-getter (B) & 0 & 0 & 0 \\
\hline Closing Marker (C) & 4 & 20 & 3 \\
\hline $\begin{array}{ll}\text { Regret Marker } & \text { (D) }\end{array}$ & 0 & 0 & 0 \\
\hline Gratitude Marker (E) & 2 & 0 & 1 \\
\hline
\end{tabular}

Based on the finding in table IX and $\mathrm{X}$ about sumimasen as closing marker, it concludes that there is no Indonesian cultural interference toward the use of sumimasen. There are numbers or incorrect answers from respondent in answering the questionnaire. It is not caused by Indonesian cultural interference; it is indeed caused by their unfamiliarity with the word sumimasen as closing marker. It is also caused by respondents' carefulness in understanding the conversational context at number IX and $\mathrm{X}$. Therefore, it concludes that there 
is no Indonesian cultural interference toward the use of the word sumimasen as closing marker.

The deficiency of Indonesian cultural interference toward the use of sumimasen as closing marker is caused by the same meaning of the word sumimasen either in Indonesian or Japanese conversational context. The context is used to close the interaction as well as used as a politeness manner in closing the conversation between the speaker and the listener.

The same function above causes Indonesian cultural interference deficiency in term of using the word sumimasen as closing marker. Furthermore, it concludes that the phenomenon happened is caused by the same sumimasen function in case of Indonesian or Japanese conversational context.

\section{CONCLUSION}

After distributing the questionnaire about the use of sumimasen to the respondents, it concludes several findings as follows:

- There is Indonesian cultural interference toward the use of the word sumimasen for students of the Japanese Literature Study Program for 2014. Interference is found in the use of the word sumimasen which functions as a gratitude marker or a thank you sign. This is because of the difference concepts in the meaning of 'thank you' in Indonesian culture which contains no remorse.
- There is no Indonesian cultural interference toward the use of sumimasen in regret marker, attention-getter, request marker and closing marker in students at Japanese literature study program academic year 2014 .

\section{REFERENCES}

[1] L. I. Ardiana, Analisis Kesalahan Berbahasa, Jakarta: Universitas Terbuka, 2010

[2] M. Arikawa, Isshoni Ite Tanoshii Hito.Tsukareru Hito, Tokyo: Kindle 2017.

[3] Chaer, and Agustina, Sosiolinguistik Sebuah Perkenalan Awal, Jakarta, Rineka Cipta, 2010.

[4] H. Enomoto, and K. Sumimasen no, Tokyo: Nihon Kezai Shinbun, 2012.

[5] Iskandar, Metodologi Penelitian Pendidikan dan Sosial (Kualitatif dan Kuantitatif), Jakarta: Gaung Persada Press, 2013.

[6] Kimura, and Kazumi, "The Multiple Functions of Sumimasen," Issues in Applied Linguistics, vol. 5, Issue 2. Los Angeles: UCLA Department of Linguistics, 1994.

[7] K. Mari, N. Michiko, M. Satoko, and H. Mari, Kiku Kangeru Hanasu Ryuugakusei no Tame no Shokyuu Nihongo Kaiwa. Tokyo: 3A Corporation, 2009. 